\title{
Dynamics of GnRH Neuron Ionotropic GABA and Glutamate Synaptic Receptors Are Unchanged during Estrogen Positive and Negative Feedback in Female Mice
}

\author{
(D)Xinhuai Liu, Robert Porteous, and ${ }^{\circledR}$ Allan E. Herbison
}

DOI:http://dx.doi.org/10.1523/ENEURO.0259-17.2017

Centre for Neuroendocrinology and Department of Physiology, University of Otago School of Biomedical Medical Sciences, Dunedin 9054, New Zealand

\begin{abstract}
Inputs from GABAergic and glutamatergic neurons are suspected to play an important role in regulating the activity of the gonadotropin-releasing hormone $(\mathrm{GnRH})$ neurons. The $\mathrm{GnRH}$ neurons exhibit marked plasticity to control the ovarian cycle with circulating estradiol concentrations having profound "feedback" effects on their activity. This includes "negative feedback" responsible for suppressing GnRH neuron activity and "positive feedback" that occurs at mid-cycle to activate the GnRH neurons to generate the preovulatory luteinizing hormone surge. In the present study, we employed brain slice electrophysiology to question whether synaptic ionotropic GABA and glutamate receptor signaling at the $\mathrm{GnRH}$ neuron changed at times of negative and positive feedback. We used a well characterized estradiol (E)-treated ovariectomized (OVX) mouse model to replicate negative and positive feedback. Miniature and spontaneous postsynaptic currents (mPSCs and sPSCs) attributable to $\mathrm{GABA}_{\mathrm{A}}$ and glutamatergic receptor signaling were recorded from $\mathrm{GnRH}$ neurons obtained from intact diestrous, OVX, OVX $+E$ (negative feedback), and OVX $+E+E$ (positive feedback) female mice. Approximately $90 \%$ of $\mathrm{GnRH}$ neurons exhibited spontaneous $\mathrm{GABA}_{\mathrm{A}}$-mPSCs in all groups but no significant differences in the frequency or kinetics of mPSCs were found at the times of negative or positive feedback. Approximately $50 \%$ of $\mathrm{GnRH}$ neurons exhibited spontaneous glutamate mPSCs but again no differences were detected. The same was true for spontaneous PSCs in all cases. These observations indicate that the kinetics of ionotropic GABA and glutamate receptor synaptic transmission to $\mathrm{GnRH}$ neurons remain stable across the different estrogen feedback states.
\end{abstract}

Key words: electrophysiology; estradiol; GABA; glutamate; GnRH

\section{Significance Statement}

The gonadotropin-releasing hormone $(\mathrm{GnRH})$ neurons are the key output cells controlling fertility in all mammals. Glutamatergic and GABAergic inputs are hypothesized to play a key role in mediating the so-called "negative" and "positive" feedback actions of circulating estradiol on GnRH neuron firing. These feedback actions are critical for the GnRH neurons to control the fluctuating levels of reproductive hormones that occur across the ovarian cycle. We show here that the dynamics of synaptic ionotropic GABA and glutamate receptors on $\mathrm{GnRH}$ neurons do not change in relation to estradiol negative and positive feedback. This indicates that changes in presynaptic GABA/glutamate release may be more important that postsynaptic mechanisms in the control of $\mathrm{GnRH}$ neuron firing across the ovarian cycle. 


\section{Introduction}

Inputs from glutamatergic and GABAergic neurons are thought to play a major role in defining the electrical behavior of the gonadotropin-releasing hormone $(\mathrm{GnRH})$ neurons that control fertility (Jennes et al., 2002; Moenter et al., 2009; Iremonger et al., 2010; Herbison and Moenter, 2011). Essentially all $\mathrm{GnRH}$ neurons express functional AMPA, $G_{A B A}$, and $G A B A_{B}$ receptors with sub-populations having NMDA and kainate receptors (Iremonger et al., 2010; Herbison and Moenter, 2011). Whereas the activation of $\mathrm{GABA}_{\mathrm{B}}$ receptors inhibits the electrical excitability of GnRH neurons (Zhang et al., 2009; Liu and Herbison, 2011), the activation of ionotropic GABAergic and glutamatergic receptors is excitatory (Yin et al., 2008; Iremonger et al., 2010; Herbison and Moenter, 2011). While it is clear that amino acid transmitters can have profound effects on the electrical excitability of GnRH neurons, their physiologic roles remain uncertain.

Many studies have examined the effects of manipulating hypothalamic glutamate and $\mathrm{GABA}_{\mathrm{A}}$ receptor occupancy on the secretion of gonadotropins in vivo. These have suggested key roles for amino acid transmitters in the onset of puberty (Terasawa and Fernandez, 2001; Clarkson and Herbison, 2006), generation of pulsatile and surge modes of luteinizing hormone (LH) secretion (Brann and Mahesh, 1997; Jackson and Kuehl, 2002; Mitsushima et al., 2003; Herbison, 2015) and seasonal transitions in fertility (Scott and Clarke, 1993; Jansen et al., 2003). However, as all neurons express ionotropic GABA and glutamate receptors, it has been difficult to assess the functional impact of amino acid signaling directly at the $\mathrm{GnRH}$ neuron. The same difficulty exists for in vivo microinfusion investigations that have attempted to modulate $\mathrm{GABA}_{A}$ receptor occupancy within the immediate vicinity of the $\mathrm{GnRH}$ neuron cell bodies (Herbison et al., 1991; Jarry et al., 1991). Furthermore, investigations using mice with $\mathrm{GnRH}$ neuron-selective deletion or knockdown of $G_{A B A}$ and NMDA receptors have also failed to offer any clear insight into the physiologic roles of direct amino acid signaling at the GnRH neuron (Shimshek et al., 2006; Lee et al., 2010).

An alternative approach to understanding the significance of GABA and glutamate signaling at the $\mathrm{GnRH}$ neuron has been to use whole-cell patch clamp electro-

Received July 24, 2017; accepted October 22, 2017; First published October 31, 2017.

The authors declare no competing financial interests.

Author contributions: X.L. and A.E.H. designed research; R.P. and X.L. performed research; X.L. analyzed data; A.E.H. and X.L. wrote the paper.

This work was supported by the New Zealand Health Research Council.

Acknowledgements: We thank Dr. Karl Iremonger and Dr. Richard Piet for reviewing an early version of this manuscript.

Correspondence should be addressed to Allan E. Herbison, Centre for Neuroendocrinology and Department of Physiology, University of Otago School of Biomedical Medical Sciences, Dunedin 9054, New Zealand, E-mail: allan.herbison@otago.ac.nz.

DOI:http://dx.doi.org/10.1523/ENEURO.0259-17.2017

Copyright @ 2017 Liu et al.

This is an open-access article distributed under the terms of the Creative Commons Attribution 4.0 International license, which permits unrestricted use, distribution and reproduction in any medium provided that the original work is properly attributed. physiology in acute brain slices. This has enabled the dynamics of GABA and glutamate receptors expressed by $\mathrm{GnRH}$ neurons to be assayed over a range of different experimental conditions (Moenter, 2010; Herbison and Moenter, 2011). Of particular importance, studies by the Moenter laboratory have revealed robust changes in the frequency and amplitude of amino acid postsynaptic currents (PSCs) exhibited by GnRH neurons during estrogen negative and positive feedback. In terms of negative feedback, the frequency of both $\mathrm{GABA}_{\mathrm{A}}$ and AMPA receptor PSCs, and amplitude of AMPA PSCs, were reduced in ovariectomized (OVX) plus estrogen (OVX + E) mice compared with OVX animals (Christian and Moenter, 2007; Christian et al., 2009). At the time of positive feedback just before or during the LH surge, both the frequency and amplitude of $G_{A B A}$ PSCs were enhanced while no change was observed for AMPA PSCs (Christian and Moenter, 2007; Christian et al., 2009). Compatible with the substantial loss of neural inputs to cells in brain slices, these changes in PSC frequency arose from alterations in spontaneous vesicle release rather than action potentialdependent release of amino acids. Nevertheless, these findings indicated that synaptic GABA transmission at the $\mathrm{GnRH}$ neuron was changing at times of both positive and negative feedback, whereas AMPA receptor dynamics rearranged only during negative feedback. Although correlative, these results suggested that GABA and glutamate inputs to $\mathrm{GnRH}$ neurons were involved in transitioning $\mathrm{GnRH}$ neuron behavior across the estrous cycle (Moenter et al., 2009). This is an important concept given that the $\mathrm{GnRH}$ neurons themselves do not express estrogen receptor- $\alpha$ (ESR1), the receptor mediating estrogen negative and positive feedback (Herbison, 2015; Levine, 2015).

The limitation of prior GABA and glutamate PSC studies on $\mathrm{GnRH}$ neurons is that they were all undertaken in an unusual mouse model in which mice fluctuate between negative and positive feedback on a daily basis in response to constant high levels of estradiol (Christian et al., 2005). This is unlike the physiologic situation where serum estradiol levels increase gradually over $3 d$ to generate positive feedback, with negative feedback being present at all other times (Herbison, 2015; Levine, 2015). As such, we were interested in re-assessing GABA and glutamate PSCs in GnRH neurons in mouse models that more closely follow the natural estrous cycle. Developed originally by Bronson (Bronson, 1981), these models involve ovariectomy and immediate insertion of an estradiol-filled SILASTIC capsule to provide low levels of serum estradiol that generate only negative feedback. After $5 \mathrm{~d}$, these negative feedback OVX + E mice can then be given a supplemental injection of estradiol benzoate $(\mathrm{OVX}+\mathrm{E}+\mathrm{E})$ to mimic the diestrous/proestrous rise in estradiol that generates positive feedback and the LH surge $2 \mathrm{~d}$ later. Using these mouse models, and intact diestrous mice to compare with OVX $+\mathrm{E}$ animals, we have now reexamined whether glutamate and $\mathrm{GABA}_{\mathrm{A}}$ receptor PSCs are altered in $\mathrm{GnRH}$ neurons during negative and positive feedback. 


\section{Materials and Methods}

\section{Mouse models}

Adult female (131 \pm 5 d of age) C57BL/6 GnRH-GFP mice (Spergel et al., 1999) were housed under a 12/12 h light/dark cycle (lights on 6 A.M., off at 6 P.M.) with ad libitum access to food and water in groups of two or three animals per cage. Vaginal cytology of intact females was examined daily at 10 A.M. to determine the diestrous stage of the estrous cycle for mice used in the intact control group. Other mice were anaesthetised with isoflurane anesthesia and OVX 7-10 d before being used in electrophysiological experiments. "OVX" mice received no estradiol treatments. "OVX + E mice" were implanted with subcutaneous SILASTIC implants containing $17 \beta$ estradiol (1 $\mu \mathrm{g} / 20 \mathrm{~g}$ body weight; Bronson, 1981) at the time of ovariectomy and used for electrophysiology experiments 7-10 d (mode $=8$ ) later. At this time OVX $+\mathrm{E}$ mice exhibit negative feedback with pulsatile LH secretion slowed to the same frequency as intact diestrous mice (Czieselsky et al., 2016). OVX, OVX + E, and diestrous mice were killed at 1:00-1:30 P.M. and brain slices recorded from 2:30-5:00 P.M. A further group of OVX + E mice were given a subcutaneous injection of estradiol benzoate $(1 \mu \mathrm{g} / 100 \mu \mathrm{l})$ at 9 A.M. $6 \mathrm{~d}$ after SILASTIC capsule implantation (OVX + E+E; Bronson, 1981) and used for electrophysiology experiments the following day. These OVX + E+E mice were killed at 4:00-4:30 P.M. and brain slices recorded at "surge onset" from 5:00-7:30 P.M. OVX + E+E mice exhibit an LH surge that starts at 5:30 P.M. (Czieselsky et al., 2016). All animal procedures were performed in accordance with the University of Otago animal care committee's regulations.

\section{Brain slice preparation and electrophysiology}

The dissected brain was glued to a round aluminum platform and then submerged in the cooled $\left(\sim 2^{\circ} \mathrm{C}\right)$ artificial CSF (aCSF) containing high $(6 \mathrm{mM}) \mathrm{MgCl}_{2}$ and low (0.5 mM) $\mathrm{CaCl}_{2}$ and equilibrated with $95 \% \mathrm{O}_{2}, 5 \% \mathrm{CO}_{2}$. The $250-\mu \mathrm{m}$-thick sagittal brain slices were cut using a vibratome (Leica VT1000S). Sagittal slices were used based on prior work showing sagittal slices to exhibit the most dynamic PSC changes in estrogen-treated OVX mice (Christian and Moenter, 2007). Brain slices were incubated for at least $1 \mathrm{~h}$ in equilibrated $\left(95 \% \mathrm{O}_{2}, 5 \% \mathrm{CO}_{2}\right)$ aCSF, containing $118 \mathrm{mM} \mathrm{NaCl}, 3 \mathrm{mM} \mathrm{KCl}, 2.5 \mathrm{mM}$ $\mathrm{CaCl}_{2}, 1.2 \mathrm{mM} \mathrm{MgCl}_{2}, 11 \mathrm{mM}$ D-glucose, $10 \mathrm{mM}$ HEPES, and $25 \mathrm{mM} \mathrm{NaHCO}_{3}$ with $\mathrm{pH} 7.3$ at $30^{\circ} \mathrm{C}$, before being transferred to a submerged recording chamber where they were perfused with aCSF at 2-3 $\mathrm{ml} / \mathrm{min}$ maintained at $32 \pm 1^{\circ} \mathrm{C}$. Whole-cell recordings of $\mathrm{GnRH}$ neurons were undertaken using a fixed-stage upright fluorescence microscope (BX51WI; Olympus) with GFP-tagged $\mathrm{GnRH}$ neurons identified briefly ( $<10 \mathrm{~s}$ ) using fluorescence and then patched under Nomarski differential interference contrast optics ( $40 \times$ water-immersion objective). Patch pipettes were pulled from glass capillaries (inner diameter, $1.17 \mathrm{~mm}$; outer diameter, $1.5 \mathrm{~mm}$ ) with a microelectrode puller (Sutter Instruments) and had 4-6 MOhm resistance when filled with the pipette solution composed of $130 \mathrm{mM}$ K-gluconate (glutamate PSCs) or $130 \mathrm{mM} \mathrm{KCl}\left(\mathrm{GABA}_{\mathrm{A}}\right.$
PSCs), $5 \mathrm{mM} \mathrm{NaCl}, 0.22 \mathrm{mM} \mathrm{CaCl}_{2}, 10 \mathrm{mM}$ HEPES, $2 \mathrm{mM}$ BAPTA, 2 mM MgATP, 2 mM Na ATP $_{2} 0.2$ mM Na ${ }_{2}$ GTP, and $10 \mathrm{mM}$ phosphocreatine-Tris ( $\mathrm{pH} 7.35$ adjusted by $\mathrm{KOH}, \sim 290$ mOsmol).

Signals (voltage and current) were amplified with a Multiclamp 700B amplifier (CV7B; Molecular Devices) and sampled on-line with the use of a Digidata 1440A interface (Molecular Devices) connected to a personal computer. Signals were filtered with Bessel filter of Multiclamp 700B (at $3 \mathrm{KHz}$ for current or $10 \mathrm{kHz}$ for voltage) before being digitized at a rate of $10 \mathrm{kHz}$. Acquisition and subsequent analysis of the acquired data were performed with the Clampex 10 suite of software (Molecular Devices) and Origin Pro 7.5 (OriginLab). Resting membrane potential was determined in current clamp without any holding current and liquid junction potentials of $\sim 12 \mathrm{mV}$ uncorrected for the gluconate-based solution. The input resistance was determined by pClampex 10 membrane test while holding the cell at $-70 \mathrm{mV}$. During experiments, the access resistance $(\mathrm{Ra}=12 \pm 0.3 \mathrm{M} \Omega, N=138)$ was checked regularly.

After attaining a stable whole-cell voltage-clamp recording held at $-70 \mathrm{mV}$, the aCSF was switched to one containing the appropriate amino acid receptor antagonists (see below), and 2 min later, spontaneous PSCs (sPSCs) were recorded for 3-4 min. The perfusion medium was then changed to one containing tetrodotoxin (TTX), in addition to the amino acid receptor antagonists, and 2 min later miniature PSCs (mPSCs) recorded for 3-4 min. At the conclusion of the recording, the brain slice was removed and a new slice used for the next cell. Two to four cells were obtained from each animal. If a healthy cell did not exhibit PSCs, its PSC mean frequency was considered to be zero with no parameters being measured. A cell was considered to be healthy if its input resistance was $>450 \mathrm{M} \Omega$, series resistance $\leq 23 \mathrm{M} \Omega$ (without change during the data collection), membrane capacitance $\geq 14 \mathrm{pF}$, resting membrane potential below $-47 \mathrm{mV}$ and action potential amplitude $>80 \mathrm{mV}$.

\section{Drugs}

Stock solutions of D-2-amino-5-phosphonovaleric acid (AP5), GABAzine, 6-cyano-7-nitroquinoxaline-2,3-dione (CNQX; Sigma Ltd), and TTX (Alomone Labs) were prepared in double distilled $\mathrm{H}_{2} \mathrm{O}$ at $10^{3}$ times final concentration. All stock solutions were stored at $-20^{\circ} \mathrm{C}$. All drugs were applied in the perfusion solution with final concentration as indicated. The mixture of CNQX $(10 \mu \mathrm{M})$ and AP5 $(50 \mu \mathrm{M})$ was used to block all glutamatergic ionotropic receptor-mediated synaptic transmission. GABAzine $(5 \mu \mathrm{M})$ was used to block all GABAergic ionotropic receptor-mediated synaptic transmission. TTX $(0.5 \mu \mathrm{M})$ was used to block all action potential-dependent transmission.

\section{Analysis}

PSCs were detected by the MiniAnalysis program (Synptosoft, NJ07024) and confirmed by eye with detection errors corrected manually. All PSCs occurring over two 3-min periods were analyzed for each cell with a maximum of 300 PSCs/period being analyzed for any one 
cell. Analysis parameters included mean frequency (number of PSCs divided by $180 \mathrm{~s}$ or, for cells displaying many PSCs, the number of seconds during which 300 PSCs occurred), average inter-PSCs interval, PSC amplitude, rise time between $10 \%$ and $90 \%$ amplitude of PSCs, decay time between $10 \%$ and $90 \%$ amplitude of PSCs, and half width of PSCs. GABAergic PSCs, termed GPSCs, were obtained in the presence of AP5 $(50 \mu \mathrm{M})+$ CNQX $(10 \mu \mathrm{M})$ in the perfusion solution. In separate experiments, glutamatergic PSCs, termed excitatory PSCs (EPSCs) were obtained in the presence of GABAzine (5 $\mu \mathrm{M})$ in the perfusion solution. mPSCs were assessed by adding TTX $(0.5 \mu \mathrm{M})$ to the aCSF and analyzed in the same manner for sPSCs detailed above. Signals were passed through a low-pass filter $(1 \mathrm{KHz})$ and average PSCs and mPSCs traces obtained for each cell by aligning all events on their rising phase and these were then averaged across each experimental group.

\section{Statistical analysis}

The percentages of GnRH neurons exhibiting PSCs were compared using the $\chi^{2}$ test (among four groups) or Fisher's exact test (between two groups). Analysis of the mean frequency, inter-PSCs interval, amplitude, rise time, decay time, and half-width of PSCs was undertaken with Kruskal-Wallis nonparametric ANOVA. To compare cumulative frequency of the inter-PSC intervals or amplitude of PSCs, mean, mean +2 SD, and mean - 2 SD were pooled before applying Kruskal-Wallis nonparametric ANOVA. In all analyses, differences were considered statistically significant at $p<0.05$.

\section{Results}

\section{Miniature GABA PSCs (mGPSCs)}

In total, seven GnRH-GFP mice were used in each of the four experimental groups, yielding mGPSC recordings from 24 (diestrous), 21 (OVX), 20 (OVX + E), and 22 (OVX $+\mathrm{E}+\mathrm{E}) \mathrm{GnRH}$ neurons. Recorded cells were located predominantly within the rostral preoptic area with $4 \%$ (six of 138 cells) located in the lateral aspects of the anterior hypothalamus. Recordings undertaken in AP5, CNQX, and TTX, revealed typical mGPSCs (Fig. $1 A, B, D, E$ ) that were abolished completely by adding $5 \mu \mathrm{M}$ GABAzine to the aCSF (Fig. 1C,F).

No differences were detected in the occurrence, frequency, or dynamics of mGPSCs between diestrous and OVX mice (Figs. 1, 2; Table 1). Approximately $90 \%$ of all GnRH neurons exhibited mGPSCs in both groups (Fig. $2 A$ ) and regardless of whether cumulative probability (Fig. $1 G, H$ ) or group mean events (Fig. $2 A-C$ ) were analyzed, the inter mGPSC interval and mGPSC amplitude were not different. Similarly, the mean frequency of mGPSCs over the 3-min recording period was not different when all cells were tested (Fig. 2B) or when only cells exhibiting mGPSCs were analyzed (Fig. 2C). Rise time, decay time and half-width of GPSCs were also not different (Table 1).

The same result was found when comparing OVX with $\mathrm{OVX}+\mathrm{E}$ and $\mathrm{OVX}+\mathrm{E}+\mathrm{E}$ recordings with no statistically significant differences being detected in terms of the numbers of GnRH neurons exhibiting mGPSCs (Fig. 2A) or the frequency and dynamics of mGPSCs (Figs. 1, 2; Table 1).

\section{Spontaneous GPSCs (sGPSCs)}

sGPSCs were recorded from 25 (diestrous), 22 (OVX), $21(\mathrm{OVX}+\mathrm{E})$, and 24 (OVX + E+E) GnRH neurons, 94\% of which yielded the mGPSC results above. Recordings were undertaken in AP5 and CNQX and revealed typical sGPSCs (Fig. 3A-D).

As was found for the mGPSCs, no significant differences were detected for any SGPSC parameter between any of the experimental groups (Figs. $2 D-F, 3 A-F$; Table 1).

No significant differences were detected between mGPSCs and sGPSCs (Fig. 4; Table 1).

\section{Miniature EPSCs (mEPSCs)}

In total, five GnRH-GFP mice were used for each of the four experimental groups, yielding mEPSC recordings from 16 (diestrous), 13 (OVX), 15 (OVX + E), and 16 (OVX $+E+E) G n R H$ neurons. Recordings undertaken in the presence of GABAzine and TTX revealed mEPSCs typical of $\mathrm{GnRH}$ neurons (Fig. $5 A, B, D, E$ ) that were abolished by adding AP5 $(50 \mu \mathrm{M})+$ CNQX $(10 \mu \mathrm{M})$ to the aCSF (Fig. $5 C, F$ ). The mean half-width of mEPSCs is $\sim 1 \mathrm{~ms}$ (Table 2 ) compared with $\sim 6$ ms for mGPSCs (Table 1), suggesting that the great majority of mEPSCs recorded under the present conditions represent AMPA PSCs (Liu et al., 2011).

As expected for $\mathrm{GnRH}$ neurons (Iremonger et al., 2010), $<50 \%$ of cells exhibited mEPSCs (Fig. 6A). The most noticeable difference was that $56 \%$ of $\mathrm{GnRH}$ neurons in diestrous mice exhibited mEPSCs compared with only $23 \%$ in OVX mice ( $p>0.05$, Fisher's exact test; Fig. $6 A)$. No significant differences were found in the frequency, amplitude or dynamics of mEPSCs between diestrous and OVX mice (Figs. 5, 6A-C; Table 2). This was the case regardless of whether we assessed all cells, including those without mEPSCs as a zero value (Fig. 6B), or only cells exhibiting mEPSCs (Fig. 6C).

No statistically significant differences were found in any mEPSC parameter when comparing OVX, OVX $+\mathrm{E}$, and OVX $+\mathrm{E}+\mathrm{E}$ animals (Figs. 5, 6A-C; Table 2).

\section{Spontaneous EPSCs (sEPSCs)}

sEPSCs were recorded from 18 (diestrous), 14 (OVX), $16(\mathrm{OVX}+\mathrm{E})$, and $18(\mathrm{OVX}+\mathrm{E}+\mathrm{E}) \mathrm{GnRH}$ neurons, representing $91 \%$ of the cells providing mEPSC data above. Recordings undertaken in the presence of GABAzine revealed sEPSCs typical of $\mathrm{GnRH}$ neurons (Fig. $7 A-D)$.

Sixty percentage of $\mathrm{GnRH}$ neurons in diestrous mice exhibited sEPSCs compared with $28 \%$ in OVX mice $(p=$ 0.08 , Fisher's exact test; Fig. $5 A$ ). As was found for the mEPSCs, no significant differences were detected for any sEPSC parameter between any of the experimental groups (Figs. $6 D-F, 7$; Table 2).

No significant differences were detected between mEPSCs and SEPSCs (Fig. 8; Table 2). 


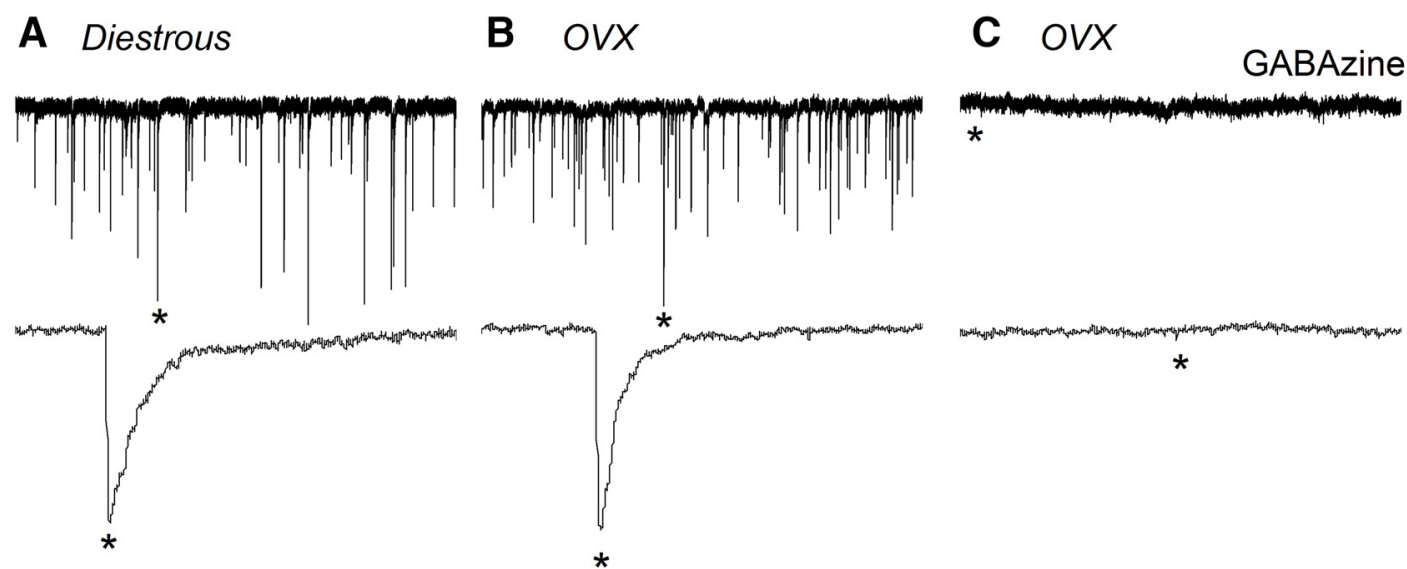

D $O V X+E$

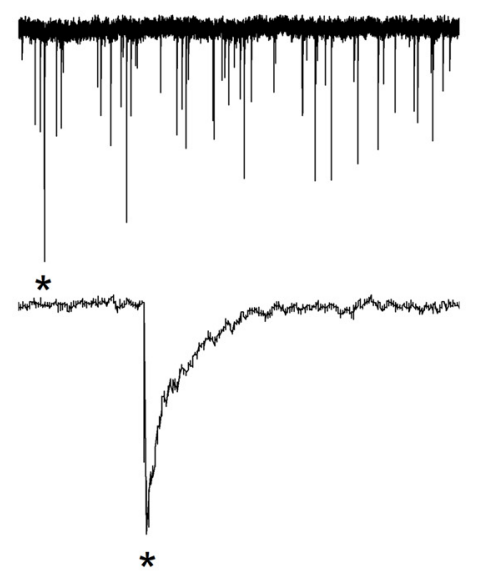

G

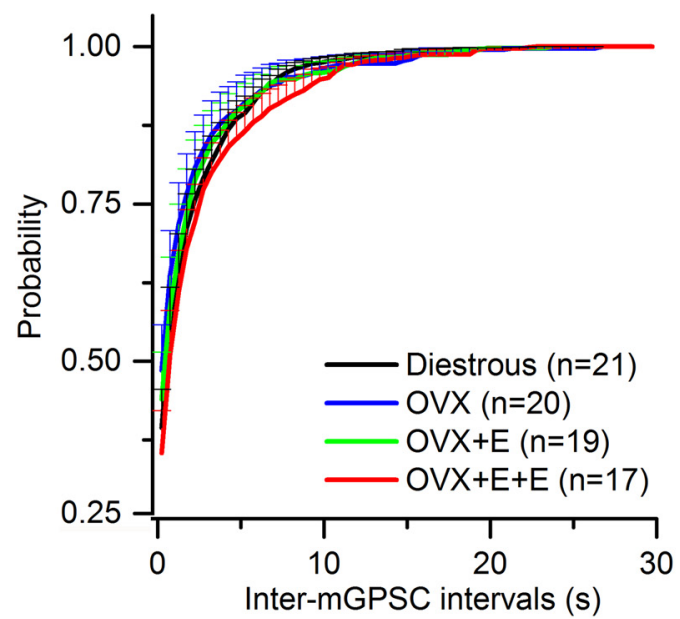

E $O V X+E+E$
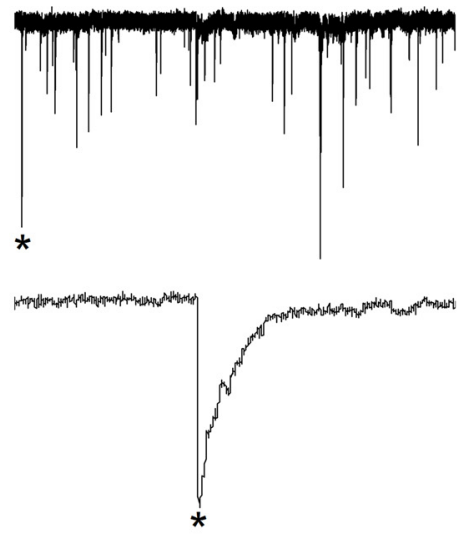

F $O V X+E+E$

GABAzine

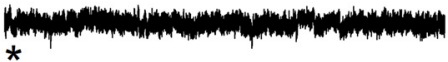

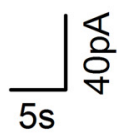

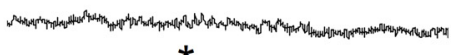

$\frac{\mathrm{d}}{30 \mathrm{~ms}}$

H

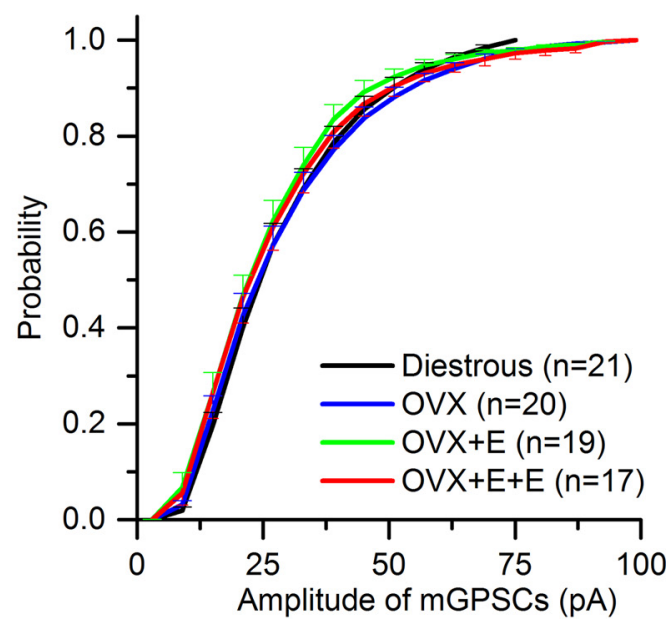

Figure 1. Miniature GABA $\mathrm{A}_{\mathrm{A}}$ receptor PSCs (mGPSCs) recorded from GnRH neurons do not change in the different mouse models of estrogen negative and positive feedback. $\boldsymbol{A}-\boldsymbol{F}$, Representative examples of mGPSC current recordings in the presence of AP5 (50 $\mu \mathrm{M}), \mathrm{CNQX}(10 \mu \mathrm{M})$, and TTX $(0.5 \mu \mathrm{M})$ taken from diestrous, OVX, OVX + E, and OVX + E+E mice. Underneath each trace an enlarged time scale of one mGPSC (*) is shown. $\boldsymbol{C}, \boldsymbol{F}$, mGPSCs are abolished by GABAzine $(5 \mu \mathrm{M})$. $\boldsymbol{G}, \boldsymbol{H}$, Cumulative plots of the average inter-mGPSC interval $(\boldsymbol{G})$ and amplitude $(\boldsymbol{H})$ in the different experimental groups (for clarity only positive SEM is shown). $N$ $=7$ for each group. Cell numbers are shown in parenthesis. Numbers of PSCs analyzed is given in Table 1. No statistically significant differences were detected for any parameter between groups. 
A

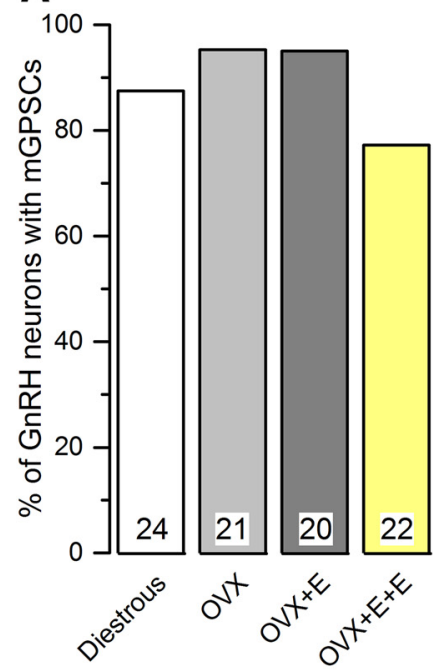

D

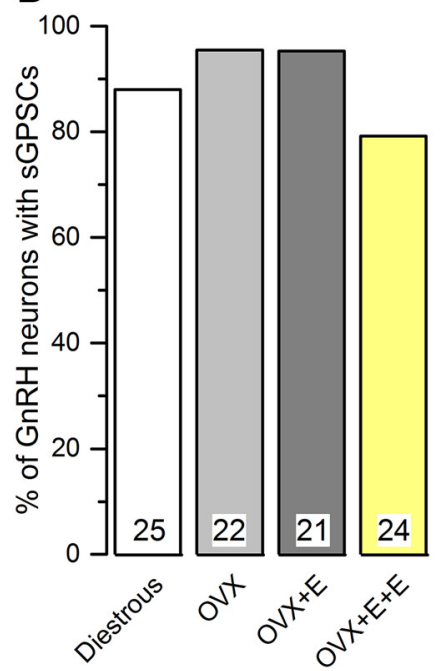

B

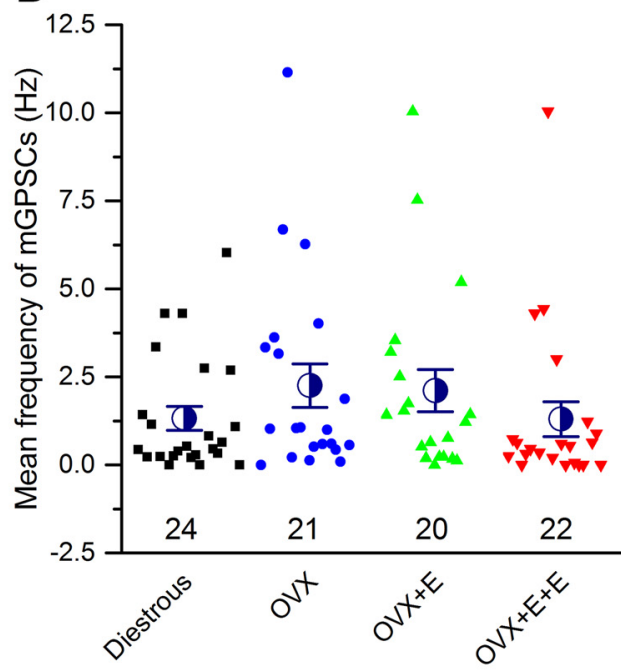

E

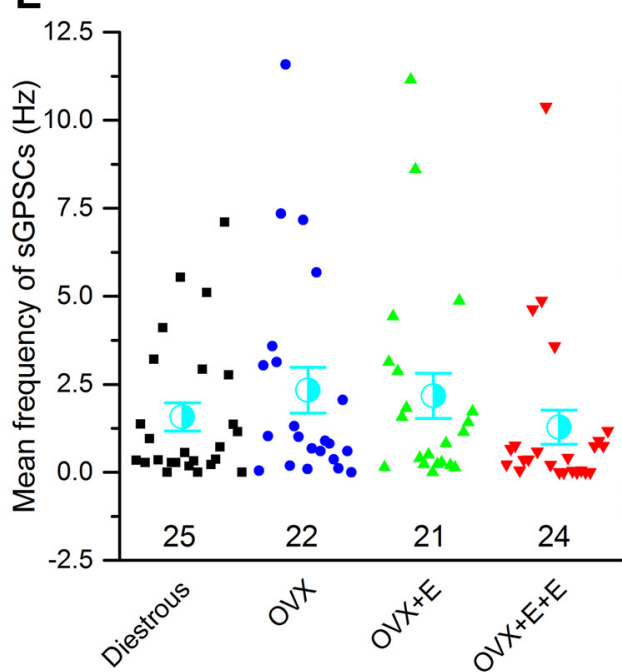

C

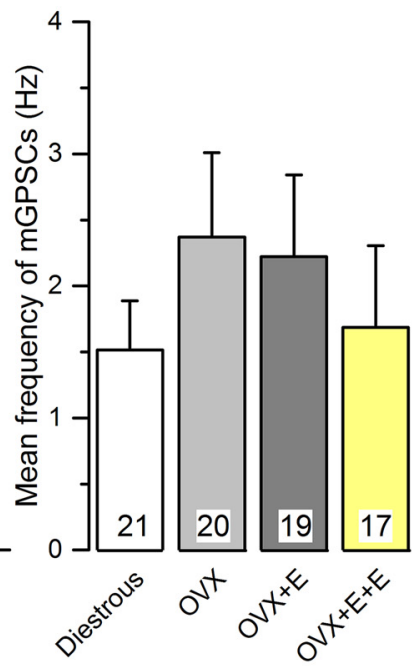

F

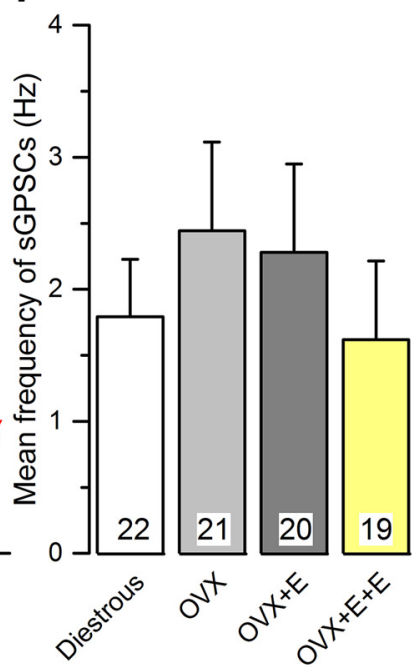

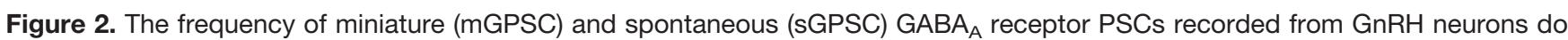
not change in the different mouse models of estrogen negative and positive feedback. $\boldsymbol{A}, \boldsymbol{D}$, Histograms showing the percentage of GnRH neurons exhibiting mGPSCs $(\boldsymbol{A})$ or sGPSCs $(\boldsymbol{D})$ in each group. $\boldsymbol{B}, \boldsymbol{E}$, Scatter plots showing the individual and mean ( \pm SEM) frequency of mGPSCs $(\boldsymbol{B})$ or sGPSCs $(\boldsymbol{E})$ in all GnRH neurons of the four experimental groups. $\boldsymbol{C}, \boldsymbol{F}$, Histograms showing the mean frequency of mGPSCs $(\boldsymbol{C})$ or sGPSCs $(\boldsymbol{F})$ from only those cells exhibiting mGPSCs $(\boldsymbol{C})$ or GPSCs $(\boldsymbol{F})$ in each animal group. Numbers at the base show the cell number. The animal number is seven for each group. No statistically significant differences were detected for any parameter between the different groups.

Table 1. Summary of GPSCs and mGPSCs in different experimental groups

\begin{tabular}{|c|c|c|c|c|c|c|c|c|}
\hline & & $\begin{array}{l}n \\
\text { (cells) }\end{array}$ & $\begin{array}{l}\text { PSCs } \\
\text { analyzed }\end{array}$ & $\begin{array}{l}\text { Inter-PSCs } \\
\text { intervals (s) }\end{array}$ & $\begin{array}{l}\text { amplitude } \\
(\mathrm{pA})\end{array}$ & $\begin{array}{l}10-90 \% \text { rise } \\
\text { time }(\mathrm{ms})\end{array}$ & $\begin{array}{l}10-90 \% \text { Decay } \\
\text { time (ms) }\end{array}$ & $\begin{array}{l}\text { Half } \\
\text { width (ms) }\end{array}$ \\
\hline Diestrus & GPSCs & 22 & 3814 & $1.92 \pm 0.37$ & $33.83 \pm 2.40$ & $1.35 \pm 0.07$ & $10.76 \pm 0.46$ & $6.28 \pm 0.37$ \\
\hline$(N=7)$ & mGPSCs & 21 & 3453 & $2.04 \pm 0.35$ & $33.46 \pm 2.10$ & $1.38 \pm 0.07$ & $11.15 \pm 0.49$ & $6.34 \pm 0.39$ \\
\hline OVX & GPSCs & 21 & 3219 & $3.09 \pm 1.20$ & $31.71 \pm 1.87$ & $1.55 \pm 0.10$ & $10.27 \pm 0.59$ & $6.10 \pm 0.40$ \\
\hline$(N=7)$ & mGPSCs & 20 & 3184 & $1.97 \pm 0.64$ & $33.17 \pm 1.66$ & $1.54 \pm 0.10$ & $10.30 \pm 0.64$ & $6.39 \pm 0.41$ \\
\hline $\mathrm{OVX}+\mathrm{E}$ & GPSCs & 20 & 2816 & $2.18 \pm 0.55$ & $30.94 \pm 1.81$ & $1.60 \pm 0.08$ & $11.15 \pm 0.80$ & $6.67 \pm 0.47$ \\
\hline$(N=7)$ & mGPSCs & 19 & 2571 & $1.98 \pm 0.51$ & $30.51 \pm 1.73$ & $1.57 \pm 0.08$ & $10.98 \pm 0.84$ & $6.72 \pm 0.62$ \\
\hline $\mathrm{OVX}+\mathrm{E}+\mathrm{E}$ & GPSCs & 19 & 3636 & $5.00 \pm 1.84$ & $31.21 \pm 2.32$ & $1.50 \pm 0.11$ & $10.43 \pm 0.54$ & $6.00 \pm 0.37$ \\
\hline$(N=7)$ & mGPSCs & 17 & 3535 & $3.21 \pm 1.11$ & $31.55 \pm 2.37$ & $1.41 \pm 0.10$ & $10.41 \pm 0.57$ & $6.07 \pm 0.40$ \\
\hline
\end{tabular}

No statistically significant differences were detected for any parameter between the groups. 
A Diestrous

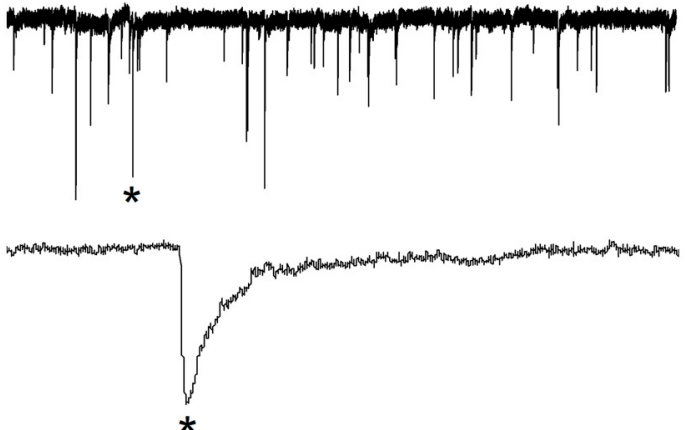

C $O V X+E$

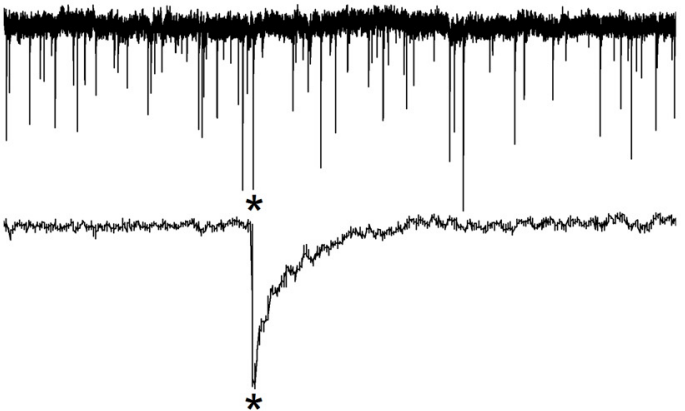

E

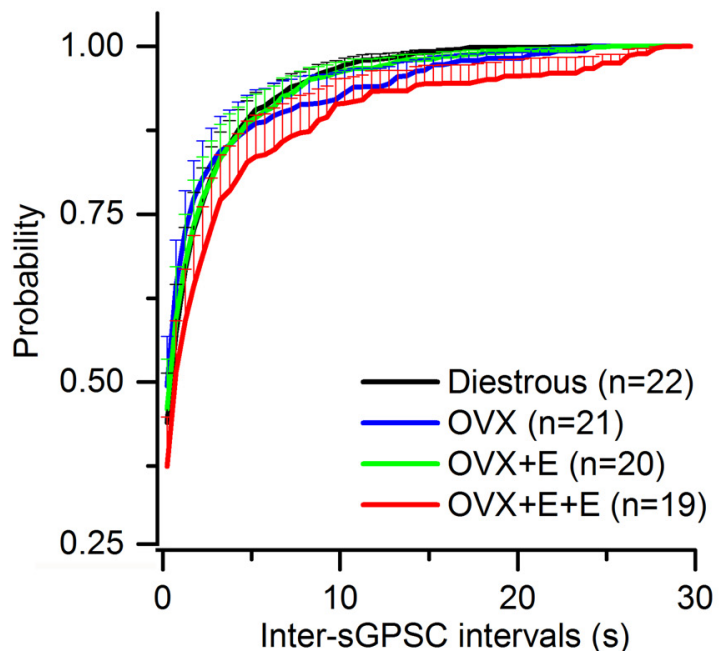

B ovx

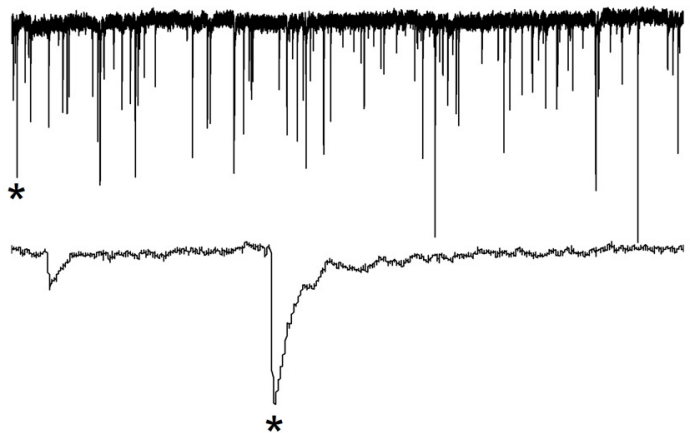

D $O V X+E+E$

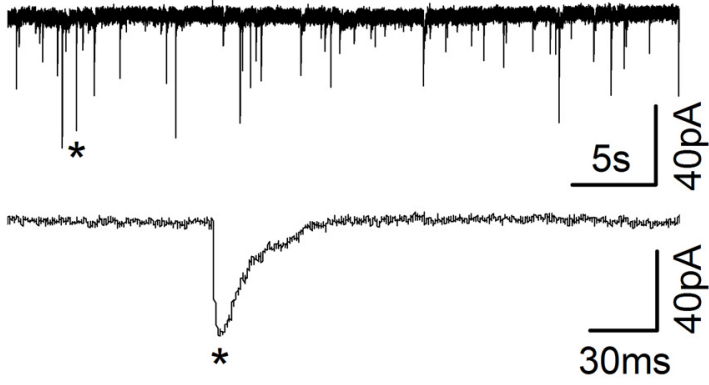

F

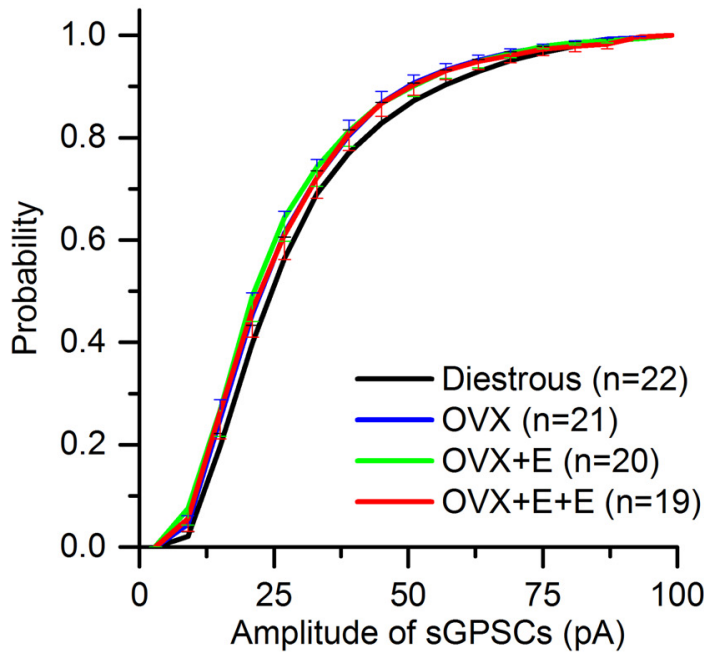

Figure 3. Spontaneous GABA receptor PSCs (sGPSCs) recorded from GnRH neurons do not change in the different mouse models of estrogen negative and positive feedback. $\boldsymbol{A}-\boldsymbol{D}$, Representative examples of sGPSC current recordings in the presence of AP5 (50 $\mu \mathrm{M})$ and CNQX $(10 \mu \mathrm{M})$ taken from diestrous, OVX, OVX $+\mathrm{E}$, and OVX + E+E mice. Underneath each trace, an enlarged time scale of one GPSC (*) is shown. $\boldsymbol{E}, \boldsymbol{F}$, Cumulative plots of the average inter-sGPSC interval $(\boldsymbol{G})$ and amplitude $(\boldsymbol{H})$ in the different experimental groups (for clarity only positive SEM is shown). $N=7$ for each group. Cell numbers are shown in parenthesis. Numbers of PSCs analyzed is given in Table 1. No statistically significant differences were detected for any parameter between groups.

\section{Discussion}

We report here that there are essentially no detectable changes in synaptic ionotropic amino acid receptor dynamics in GnRH neurons in mouse models that mirror physiologic states of estrogen negative and positive feedback. Further, we find no differences in either $G_{A B A}$ or glutamatergic PSCs when comparing diestrous and OVX mice, confirming an absence of change in relation to negative feedback. These observations are in contrast to prior studies using an OVX $+\mathrm{E}$ mouse model in which mice exhibit daily LH surges (Christian and Moenter, 2007; Christian et al., 2009). In that model, significant changes in GPSCs and EPSCs were detected in relation to daily switches in negative and positive feedback.

Differences in recording methodology are unlikely to underlie the dissimilarities between our present study and those from the daily surging studies. Recording methods and slice conditions were intentionally very similar be- 


\section{A1 Diestrous}

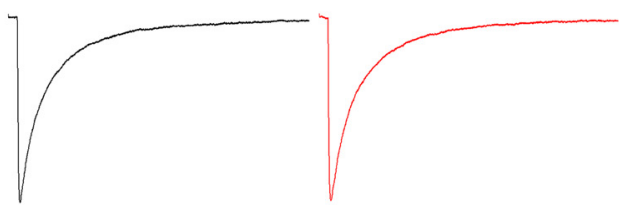

C1 ovx+E

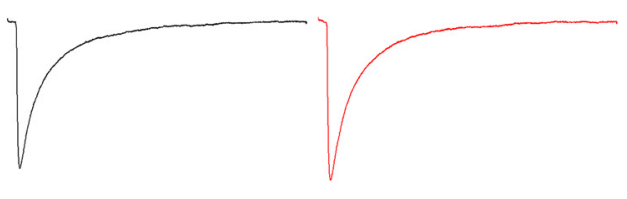

B1 ovx

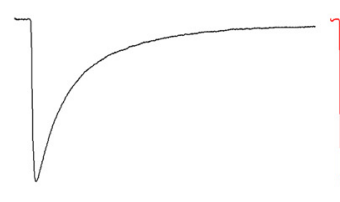

B2 ovx

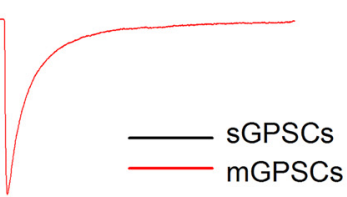

D1 $o v X+E+E \quad$ D2 $o v x+E+E$

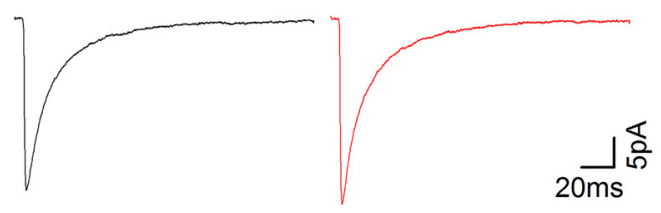

E

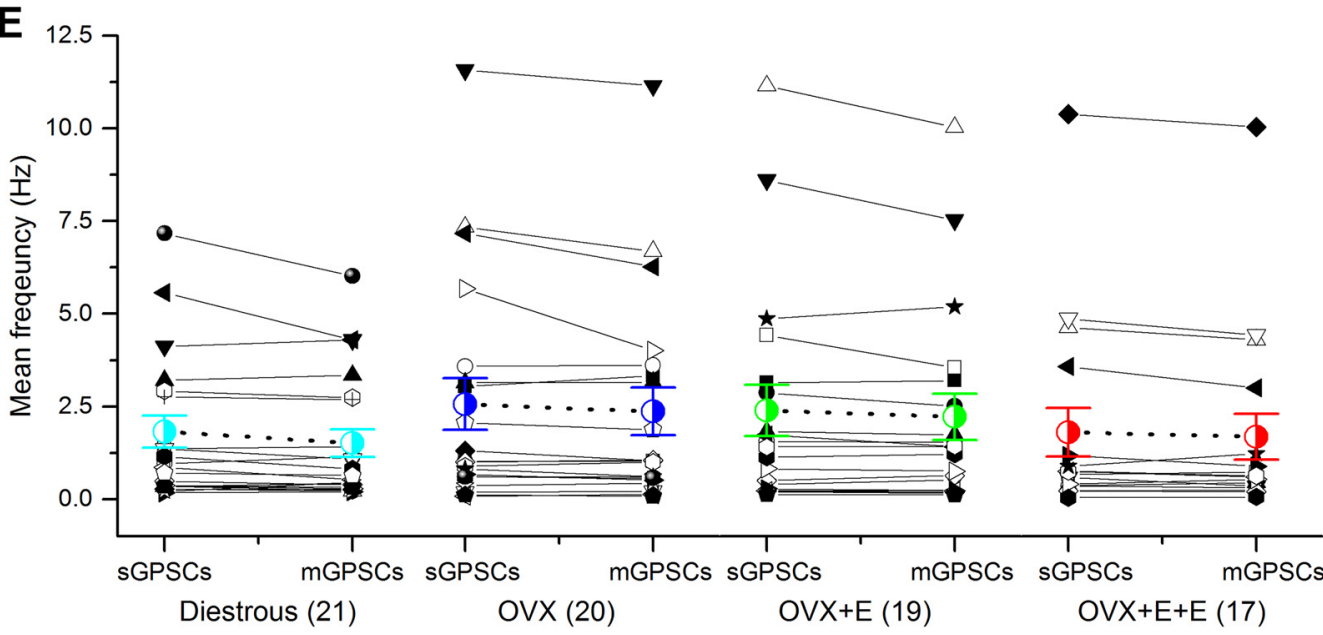

Figure 4. The kinetics and mean frequency of spontaneous (sGPSCs) and miniature (mGPSCs) PSCs are not statistically different to one another and do not change during negative and positive feedback. A1-D2, Average waveforms of sGPSCs (black) and mGPSCs (red) are depicted for each experimental group. $\boldsymbol{E}$, sGPSC and mGPSC values for individual cells (various black symbols) are plotted with group mean $( \pm S E M)$ indicated in colored symbol with dashed line. Number of individual cells in each group are given in brackets. No statistically significant differences were detected for any parameter between the different groups.

tween the studies although some technical differences do exist. For example, we use HEPES in our aCSF solution and ATP in our pipette solution, while the studies by Christian and Moenter use a sucrose aCSF cutting solution. These differences would seem unlikely to be responsible for the lack of variation in PSCs in our present studies. Although different transgenic GnRH-GFP mouse lines have been used, this again is unlikely to be significant given that both mouse lines appear to report the great majority of $\mathrm{GnRH}$ neurons present in the brain slice (Spergel et al., 1999; Suter et al., 2000). One key observation that was different between studies is the frequency of PSC events detected; in particular GPSCs, where we find GPSCs frequency to be $\sim 2 \mathrm{~Hz}$ compared with $\sim 0.5$ $\mathrm{Hz}$ in the Moenter studies (Christian and Moenter, 2007). It remains unclear why we have been able to detect much more frequent GPSCs, and slightly more frequent EPSCs, in our studies. Unfortunately, it is not possible to assess this issue independent of the different OVX $+\mathrm{E}$ models used as, to our knowledge, the present report is the first documenting GPSCs and EPSCs in GnRH neurons of intact female mice.
We believe that the primary reason for the discrepancy in GPSC and EPSC findings between studies results from the use of quite different OVX $+E$ mouse models. Under normal circumstances, the LH surge in rodents occurs once every 4-5 $\mathrm{d}$ and is driven by a gradual rise in estradiol levels over the preceding 2-3 d coupled to a circadian input that times the surge to beginning of the night (Herbison, 2008; Christian and Moenter, 2010; Levine, 2015). Recent studies undertaken in C57BL6 mice have demonstrated that the proestrous LH surge begins just before lights out and results in peak LH levels of 15-20 ng/ml (Minabe et al., 2011; Czieselsky et al., 2016; Silveira et al., 2017). The OVX + E+E model used in the present study was designed by Bronson following a meticulous series of experiments using different estradiol replacements regimens aimed at mirroring the rising follicular phase levels of circulating estradiol (Bronson, 1981). This protocol results in an LH surge beginning just before lights out but with peak LH levels of $\sim 8 \mathrm{ng} / \mathrm{ml}$, being approximately half that found in proestrous mice (Czieselsky et al., 2016). The OVX + E model used by the Moenter laboratory is intentionally designed to maintain 
A Diestrous

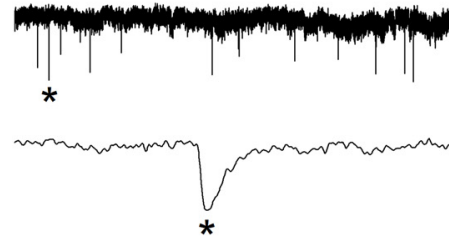

D ovX

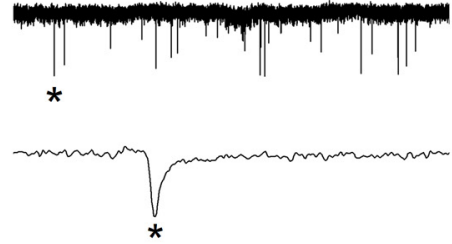

G

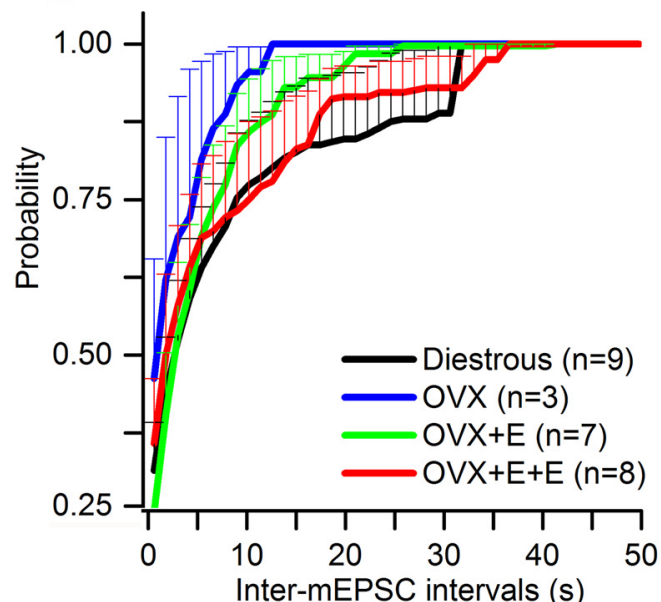

B $O V X+E$

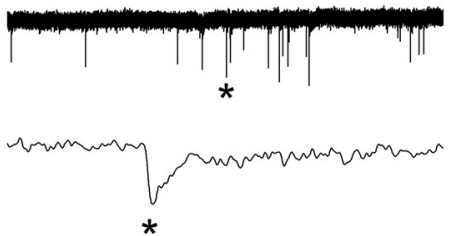

E OVX+E+E

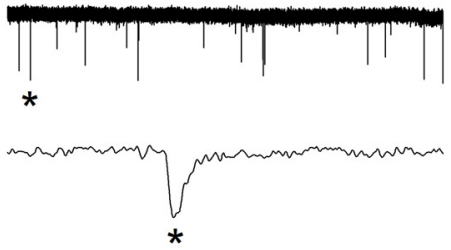

\section{C $O V X+E$}

AP5/CNQX

*

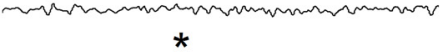

F $O V X+E+E$

AP5/CNQX

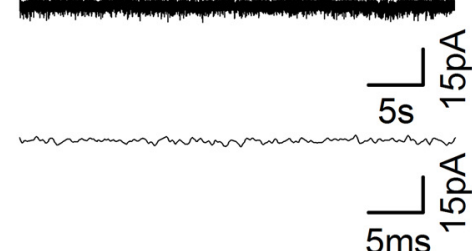

H

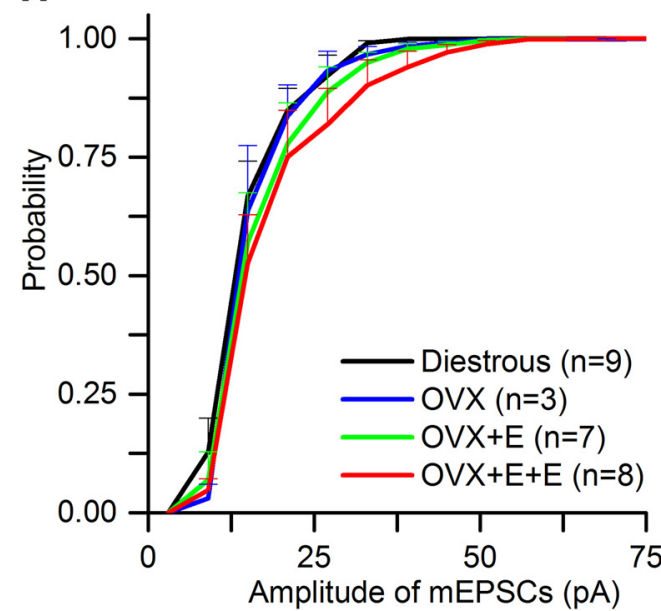

Figure 5. Miniature excitatory glutamate receptor PSCs (mEPSCs) recorded from GnRH neurons do not change in the different mouse models of estrogen negative and positive feedback. $\boldsymbol{A}-\boldsymbol{F}$, Representative examples of mEPSCs current recordings in the presence of GABAzine $(5 \mu \mathrm{M})$ and TTX $(0.5 \mu \mathrm{M})$ taken from diestrous, OVX, OVX $+\mathrm{E}$, and OVX $+\mathrm{E}+\mathrm{E}$ mice. Underneath each trace an enlarged time scale of one mEPSC $(*)$ is shown. $\boldsymbol{C}, \boldsymbol{F}, \mathrm{mEPSC}$ are abolished by AP5 $(50 \mu \mathrm{M})+\mathrm{CNQX}(10 \mu \mathrm{M})$. $\boldsymbol{G}, \boldsymbol{H}$, Cumulative plots of the average inter-mEPSC interval $(\boldsymbol{G})$ and amplitude $(\boldsymbol{H})$ in the different experimental groups (for clarity only positive SEM is shown). $N=$ 5 for each group. Cell numbers are shown in parenthesis. Numbers of PSCs analyzed is given in Table 2. No statistically significant differences were detected for any parameter between groups.

constant high proestrous levels of estradiol so as to induce both negative and positive feedback every day for several days (Christian et al., 2005). This model generates a daily $\mathrm{LH}$ surge at the time of lights out although the amplitude of these surges is very low at $\sim 1 \mathrm{ng} / \mathrm{ml} ; 10$ - to 15 -fold less than that of a proestrous surge (Christian et al., 2005; Silveira et al., 2017). Thus, there are profound differences between the mouse models used for PSCs

Table 2. Summary of EPSCs and mEPSCs in different experimental groups

\begin{tabular}{|c|c|c|c|c|c|c|c|c|}
\hline & & $\begin{array}{l}N \\
\text { (cells) }\end{array}$ & $\begin{array}{l}\text { PSCs } \\
\text { analyzed }\end{array}$ & $\begin{array}{l}\text { Inter-PSCs } \\
\text { intervals (s) }\end{array}$ & $\begin{array}{l}\text { amplitude } \\
(\mathrm{pA})\end{array}$ & $\begin{array}{l}10-90 \% \text { rise } \\
\text { time }(\mathrm{ms})\end{array}$ & $\begin{array}{l}10-90 \% \text { Decay } \\
\text { time (ms) }\end{array}$ & $\begin{array}{l}\text { Half } \\
\text { width (ms) }\end{array}$ \\
\hline Diestrus & EPSCs & 11 & 899 & $12.56 \pm 7.19$ & $20.10 \pm 2.15$ & $0.73 \pm 0.08$ & $1.37 \pm 0.14$ & $1.13 \pm 0.11$ \\
\hline$(N=5)$ & mEPSCs & 9 & 575 & $14.39 \pm 9.70$ & $17.91 \pm 1.13$ & $0.69 \pm 0.07$ & $1.14 \pm 0.06$ & $0.89 \pm 0.08$ \\
\hline OVX & EPSCs & 4 & 370 & $11.27 \pm 8.21$ & $17.83 \pm 1.15$ & $0.64 \pm 0.08$ & $1.34 \pm 0.10$ & $1.20 \pm 0.10$ \\
\hline$(N=5)$ & mEPSCs & 3 & 314 & $3.07 \pm 1.74$ & $18.23 \pm 1.50$ & $0.76 \pm 0.17$ & $1.34 \pm 0.12$ & $1.15 \pm 0.04$ \\
\hline $\mathrm{OVX}+\mathrm{E}$ & EPSCs & 8 & 769 & $5.85 \pm 7.01$ & $22.89 \pm 2.29$ & $0.63 \pm 0.07$ & $1.55 \pm 0.15$ & $1.27 \pm 0.12$ \\
\hline$(N=5)$ & mEPSCs & 7 & 496 & $5.85 \pm 1.97$ & $19.66 \pm 1.85$ & $0.61 \pm 0.06$ & $1.50 \pm 0.18$ & $1.18 \pm 0.17$ \\
\hline $\mathrm{OVX}+\mathrm{E}+\mathrm{E}$ & EPSCs & 10 & 1227 & $15.69 \pm 8.40$ & $22.57 \pm 1.79$ & $0.64 \pm 0.03$ & $1.38 \pm 0.09$ & $1.19 \pm 0.10$ \\
\hline$(N=5)$ & mEPSCs & 8 & 1113 & $7.61 \pm 3.14$ & $21.16 \pm 2.01$ & $0.65 \pm 0.03$ & $1.41 \pm 0.09$ & $1.13 \pm 0.13$ \\
\hline
\end{tabular}

No statistically significant differences were detected for any parameter between the groups. 
A

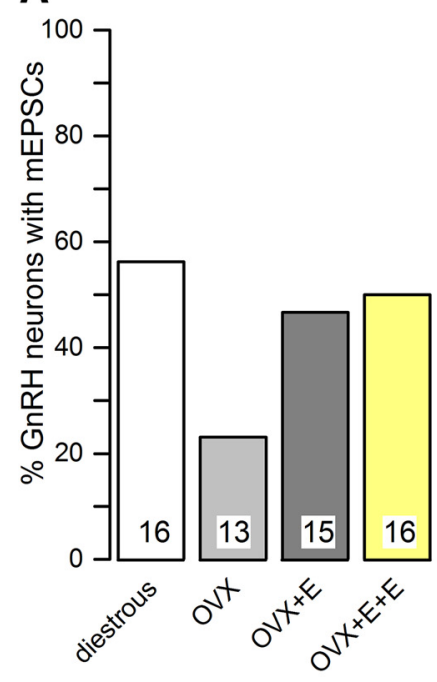

D

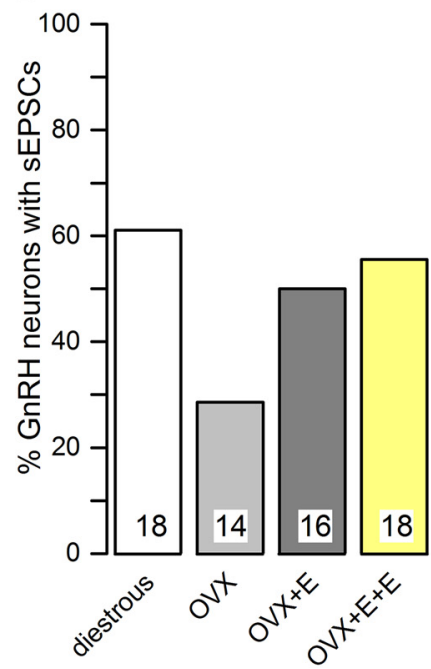

B

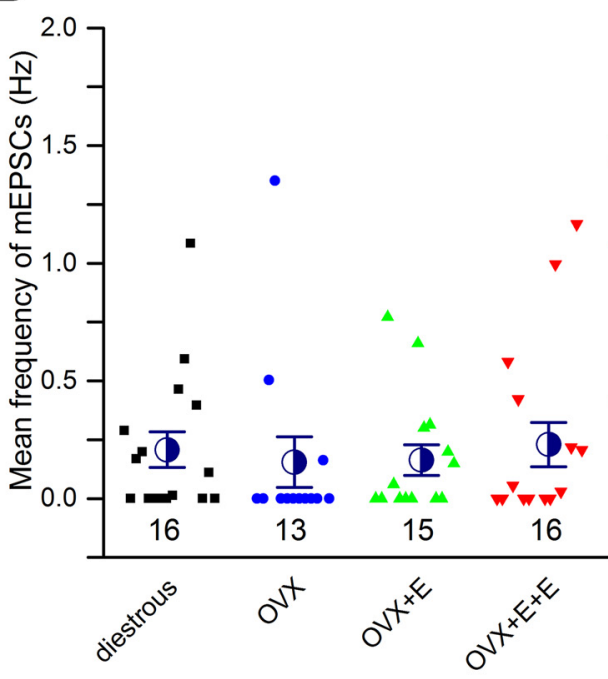

E

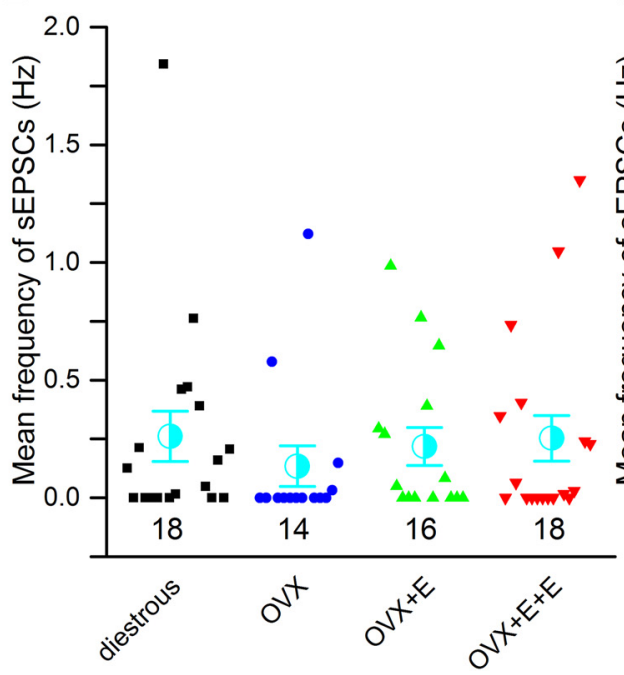

C

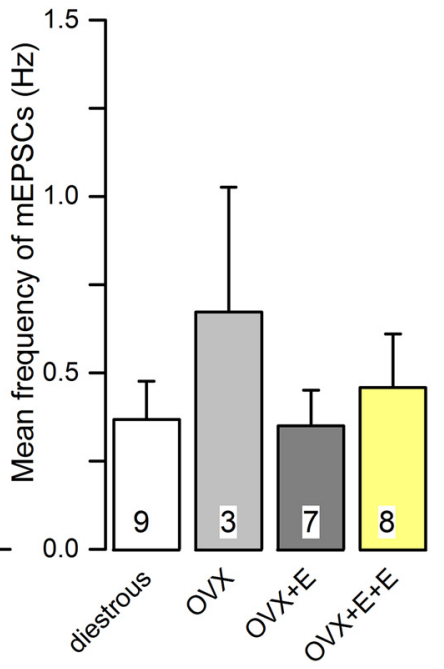

F

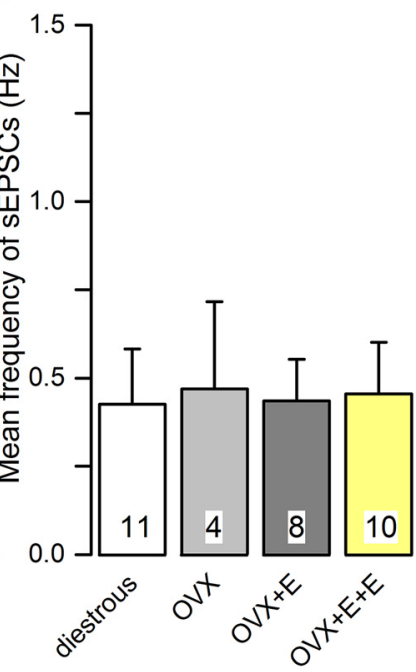

Figure 6. The frequency of excitatory glutamate miniature (mEPSCs) and spontaneous PSCs (sEPSCs) recorded from GnRH neurons do not change in the different mouse models of estrogen negative and positive feedback. $\boldsymbol{A}, \boldsymbol{D}$, Histograms showing the percentage of $\mathrm{GnRH}$ neurons with mEPSCs $(\boldsymbol{A})$ and EPSCs $(\boldsymbol{D})$ in each group. $\boldsymbol{B}, \boldsymbol{E}$, Scatter plots showing the individual and mean ( \pm SEM) frequency of mEPSCs $(\boldsymbol{B})$ or EPSCs $(\boldsymbol{E})$ in all $\mathrm{GnRH}$ neurons of the four experimental groups. $\boldsymbol{C}$, $\boldsymbol{F}$, Histograms showing the mean frequency of mEPSCs $(\boldsymbol{C})$ or sEPSCs $(\boldsymbol{F})$ from only cells exhibiting mEPSCs $(\boldsymbol{C})$ or sEPSCs $(\boldsymbol{F})$ in each animal group. Numbers at the base show the cell number. The animal number is five for each group. No statistically significant differences were detected for any parameter between the different groups.

analysis in $\mathrm{GnRH}$ neurons; one exhibits daily transitions from negative to positive feedback that are driven by circadian inputs and independent of circulating estradiol concentrations, while the other examines negative and positive feedback in a model of the natural estrous cycle.

We demonstrate that no substantial changes occur in the frequency of $\mathrm{GABA}_{A}$ or glutamate PSCs in $\mathrm{GnRH}$ neurons in relation to negative or positive feedback. This result is perhaps surprising given the substantial data implicating roles of GABA and glutamate in regulating $\mathrm{GnRH}$ neurons at times of estrogen negative and positive feedback. For example, using cell-specific deletion of Esr1 (estrogen receptor- $\alpha$ ), it was recently reported that estrogen-dependent GABA signaling was required for normal positive feedback whereas estrogen-dependent glutamatergic transmission was necessary for both negative and positive feedback (Cheong et al., 2015). Also, the numbers of dendritic spines detected on the population of $\mathrm{GnRH}$ neurons involved in the generating the $\mathrm{GnRH}$ surge increases in OVX $+\mathrm{E}+\mathrm{E}$ mice at the time of the LH surge (Chan et al., 2011).

However, it is important to recognize a number of caveats when using the brain slice approach. First, the great majority of PSCs recorded in GnRH neurons do not result from action potential-dependent GABA or glutamate release. As found in all such studies (Sim et al., 2000; Christian and Moenter, 2007; Christian et al., 2009; Penatti et al., 2010), the addition of TTX to the perfusion medium makes no substantial difference to the frequency of PSCs. Second, although the standard approach, GP- 
A Diestrous

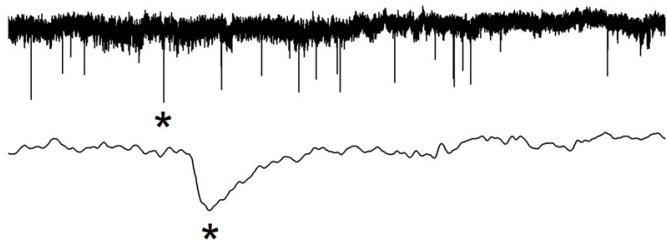

C OVX
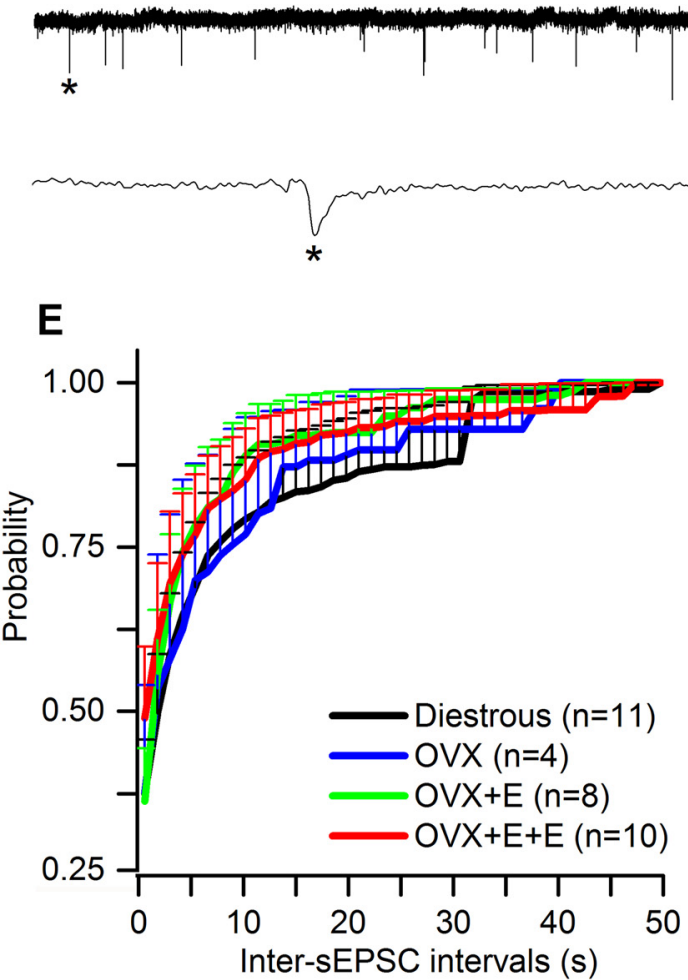

B $\quad$ OVX+E

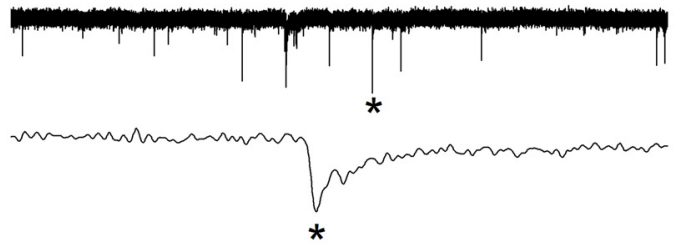

D $O V X+E+E$
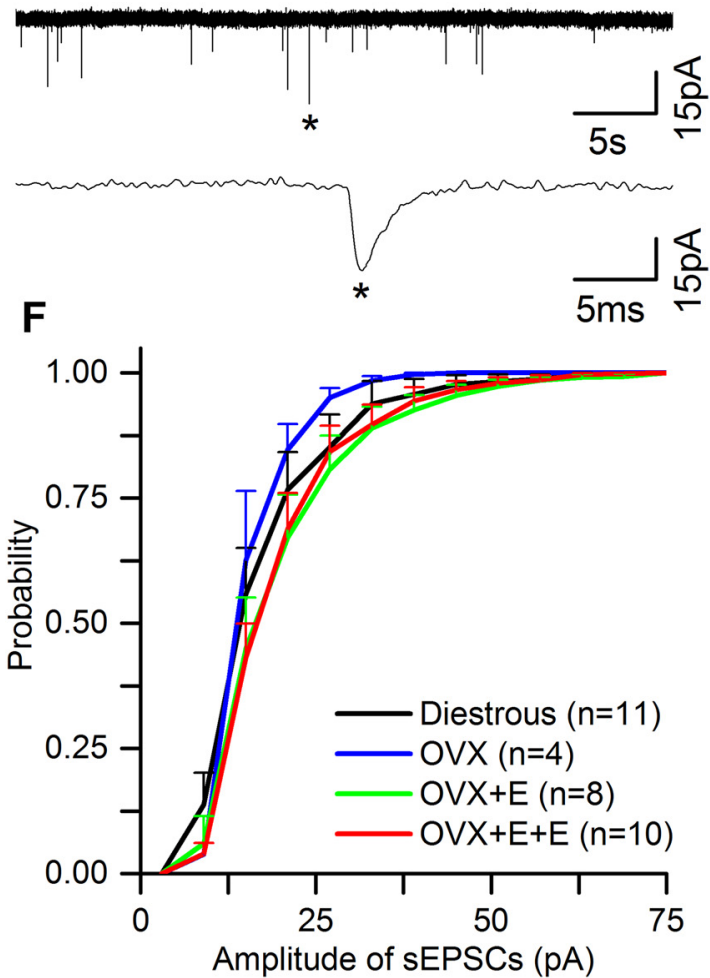

Figure 7. Spontaneous excitatory glutamate receptor PSCs (sEPSCs) recorded from GnRH neurons do not change in the different mouse models of estrogen negative and positive feedback. $\boldsymbol{A}-\boldsymbol{D}$, Representative examples of sEPSC current recordings in the presence of GABAzine ( $5 \mu \mathrm{M})$ from GnRH neurons in diestrous, OVX, OVX + E, and OVX + E+E mice. Underneath each trace an enlarged time scale of one mEPSC $(*)$ is shown $\boldsymbol{E}, \boldsymbol{F}$, Cumulative plots of the average inter-sEPSC interval $(\boldsymbol{E})$ and amplitude $(\boldsymbol{F})$ in the different experimental groups. Cell numbers are shown in parenthesis. Numbers of PSCs analyzed is given in Table 2. No statistically significant differences were detected for any parameter between any of the experimental groups.

SCs and EPSCs are measured using a whole-cell patch that results in the contents of the cell being dialyzed with that of the pipette electrode. The effects of this on PSCs amplitude, in particular, are unclear. Third, we note that neurons within the GnRH neuronal network will experience a fall in extracellular estradiol concentrations on removal from the brain and this is not supplemented in the bathing aCSF. Prior brain slice studies have shown significant effects from the sudden application of high estradiol concentrations on GnRH neuron GPSC frequency (Romanò et al., 2008; Chu et al., 2009). These and other factors may be of significance when interpreting the results of brain slice studies. Certainly, it is clear that the patterns of $\mathrm{GnRH}$ neuron firing in vivo are different to what is found in the brain slice (Constantin et al., 2013). Thus, it remains possible that substantial changes in GABA and glutamatergic drive to the $\mathrm{GnRH}$ neuron exist across the estrous cycle but, at present, it is not possible to examine these changes in vivo.

The kinetics of GPSCs and EPSCs in GnRH neurons were not altered in any of the OVX $\pm \mathrm{E}$ or diestrous groups. This suggests that no substantial changes are occurring in the subunit composition and/or post-translational modification of GABA $A$, AMPA and NMDA receptors expressed on the cell bodies and proximal dendrite of $\mathrm{GnRH}$ neurons. This is compatible with the absence of the key estrogen receptor ESR1 in GnRH neurons. Prior work indicates that the broad range of $\mathrm{GABA}_{\mathrm{A}}$ receptor subunits expressed by $\mathrm{GnRH}$ neuron narrows across postnatal development (Sim et al., 2000) but, nevertheless, many different GABA $A_{A}$ receptor subunits remain expressed by adult $\mathrm{GnRH}$ neurons (Pape et al., 2001; Todman et al., 2005; Penatti et al., 2010; Vastagh et al., 2016). Seemingly, these subunits are capable of generating multiple different $\mathrm{GABA}_{\mathrm{A}}$ receptors 
A1 Diestrous

A2 Diestrous

B1 ovx

B2 ovx

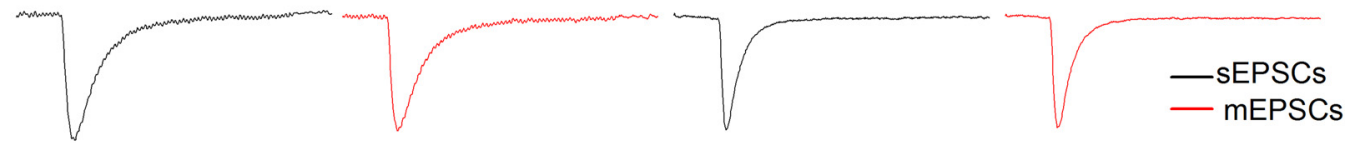

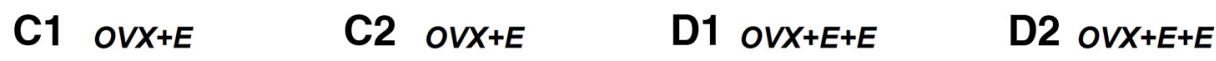

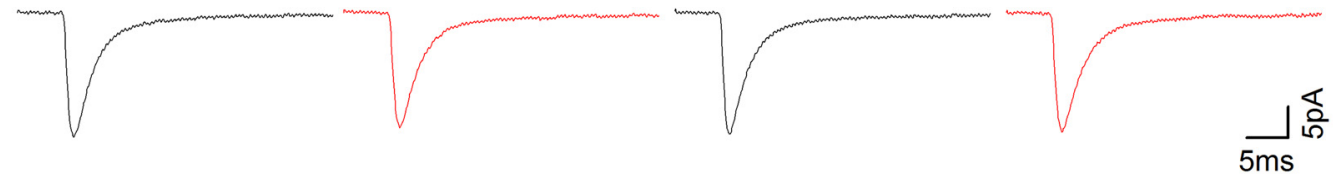

E

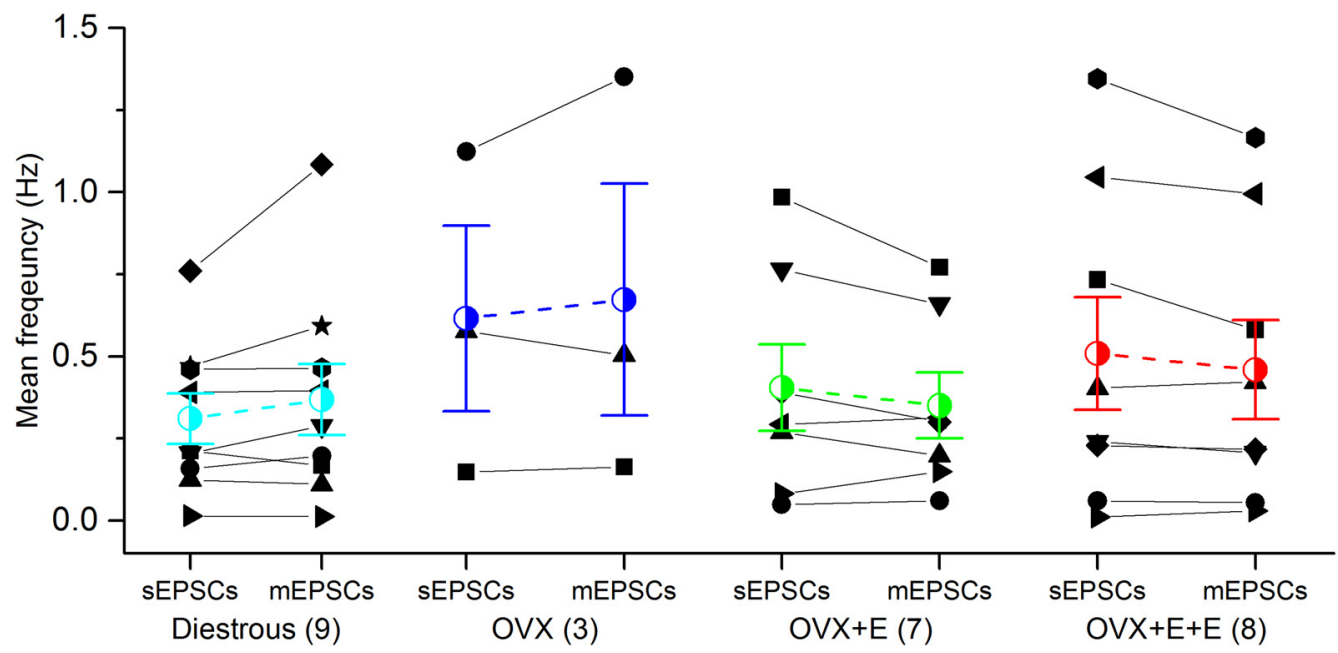

Figure 8. The kinetics and mean frequency of sEPSCs and mEPSCs are not statistically different to one another and do not change during negative and positive feedback. A1-D2, Average waveforms of sEPSCs (black) and mEPSCs (red) are depicted for each experimental group. $\boldsymbol{E}, \mathrm{sEPSC}$ and $\mathrm{mEPSC}$ values for individual cells (various black symbols) are plotted with group mean ( \pm SEM) indicated in colored symbol with dashed line. Number of individual cells in each group are given in brackets. No statistically significant differences were detected for any parameter between the different groups.

that, nevertheless, are shown here to remain stable during negative and positive feedback. The same situation exists for glutamate EPSCs that, in our recordings, represent primarily AMPA PSCs. However, we note findings in the rat where a re-arrangement of AMPA receptor subunit stoichiometry within GnRH neurons is thought to be responsible for an increase in AMPA mEPSCs frequency on proestrus (Tada et al., 2013).

In summary, we report here that ionotropic GABA and glutamate signaling to the GnRH neuron is not substantially altered in OVX $+E$ mice that model the normal estrogen negative and positive feedback processes. This does not discount the involvement or importance of amino acid signaling in these processes but does suggest that ionotropic amino acid receptor expression, at least, remains relatively stable. The observations also highlight the substantial differences that can exist between different OVX + E mouse models. The OVX + E daily surging models are not designed to mimic the normal stages of the estrous cycle but do, nevertheless, demonstrate the powerful impact of circadian influences on the $\mathrm{GnRH}$ neuron (Christian and Moenter, 2010). In this light, it is interesting to observe that the changes in GPCSs and
EPSCs encountered in that model are not found in the present model with fluctuating estrogen levels. Over and above these issues, however, these studies reinforce the need for a unified model of estrogen negative and positive feedback that can be used across laboratories examining the neurobiology of the $\mathrm{GnRH}$ neuron.

\section{References}

Brann DW, Mahesh VB (1997) Excitatory amino acids: evidence for a role in the control of reproduction and anterior pituitary hormone secretion. Endocr Rev 18:678-700. CrossRef Medline

Bronson FH (1981) The regulation of luteinizing hormone secretion by estrogen: relationships among negative feedback, surge potential, and male stimulation in juvenile, peripubertal, and adult female mice. Endocrinology 108:506-516. CrossRef Medline

Chan H, Prescott M, Ong Z, Herde MK, Herbison AE, Campbell RE (2011) Dendritic spine plasticity in gonadatropin-releasing hormone $(\mathrm{GnRH})$ neurons activated at the time of the preovulatory surge. Endocrinology 152:4906-4914. CrossRef Medline

Cheong RY, Czieselsky K, Porteous R, Herbison AE (2015) Expression of ESR1 in glutamatergic and GABAergic neurons is essential for normal puberty onset, estrogen feedback, and fertility in female mice. J Neurosci 35:14533-14543. CrossRef Medline

Christian CA, Moenter SM (2007) Estradiol induces diurnal shifts in GABA transmission to gonadotropin-releasing hormone neurons 
to provide a neural signal for ovulation. J Neurosci 27:1913-1921. CrossRef Medline

Christian CA, Moenter SM (2010) The neurobiology of preovulatory and estradiol-induced gonadotropin-releasing hormone surges. Endocr Rev 31:544-577. CrossRef Medline

Christian CA, Mobley JL, Moenter SM (2005) Diurnal and estradioldependent changes in gonadotropin-releasing hormone neuron firing activity. Proc Natl Acad Sci USA 102:15682-15687. CrossRef Medline

Christian CA, Pielecka-Fortuna J, Moenter SM (2009) Estradiol suppresses glutamatergic transmission to gonadotropin-releasing hormone neurons in a model of negative feedback in mice. Biol Reprod 80:1128-1135. CrossRef

Chu Z, Andrade J, Shupnik MA, Moenter SM (2009) Differential regulation of gonadotropin-releasing hormone neuron activity and membrane properties by acutely applied estradiol: dependence on dose and estrogen receptor subtype. J Neurosci 29:5616-5627. CrossRef Medline

Clarkson J, Herbison AE (2006) Development of GABA and glutamate signaling at the $\mathrm{GnRH}$ neuron in relation to puberty. Mol Cell Endocrinol 254-255:32-38. CrossRef Medline

Constantin S, Iremonger KJ, Herbison AE (2013) In vivo recordings of $\mathrm{GnRH}$ neuron firing reveal heterogeneity and dependence upon GABAA receptor signaling. J Neurosci 33:9394-9401. CrossRef Medline

Czieselsky K, Prescott M, Porteous R, Campos P, Clarkson J, Steyn FJ, Campbell RE, Herbison AE (2016) Pulse and surge profiles of luteinizing hormone secretion in the mouse. Endocrinology 157: 4794-4802. CrossRef Medline

Herbison AE (2008) Estrogen positive feedback to gonadotropinreleasing hormone $(\mathrm{GnRH})$ neurons in the rodent: the case for the rostral periventricular area of the third ventricle (RP3V). Brain Res Rev 57:277-287. CrossRef Medline

Herbison AE (2015) Physiology of the adult GnRH neuronal network. In: Knobil and Neill's physiology of reproduction, Ed 4 (Plant TM, Zeleznik AJ, eds), pp 399-467. San Diego: Academic Press.

Herbison AE, Moenter SM (2011) Depolarising and hyperpolarising actions of $\operatorname{GABA}(\mathrm{A})$ receptor activation on gonadotrophinreleasing hormone neurones: towards an emerging consensus. $J$ Neuroendocrinol 23:557-569. CrossRef Medline

Herbison AE, Chapman C, Dyer RG (1991) Role of medial preoptic GABA neurones in regulating luteinising secretion in the ovariectomised rat. Exp Brain Res 87:345-352. Medline

Iremonger KJ, Constantin S, Liu X, Herbison AE (2010) Glutamate regulation of $\mathrm{GnRH}$ neuron excitability. Brain Res 1364:35-43. CrossRef Medline

Jackson GL, Kuehl D (2002) Gamma-aminobutyric acid (GABA) regulation of GnRH secretion in sheep. Reprod Suppl 59:15-24. Medline

Jansen HT, Cutter C, Hardy S, Lehman MN, Goodman RL (2003) Seasonal plasticity within the gonadotropin-releasing hormone (GnRH) system of the ewe: changes in identified $\mathrm{GnRH}$ inputs and glial association. Endocrinology 144:3663-3676. CrossRef Medline

Jarry H, Leonhardt S, Wuttke W (1991) Gamma-aminobutyric acid neurons in the preoptic/anterior hypothalamic area synchronize the phasic activity of the gonadotropin-releasing hormone pulse generator in ovariectomized rats. Neuroendocrinology 53:261267. Medline

Jennes L, Lin W, Lakhlani S (2002) Glutamatergic regulation of gonadotropin-releasing hormone neurons. Prog Brain Res 141: 183-192. CrossRef Medline

Lee K, Porteous R, Campbell RE, Lüscher B, Herbison AE (2010) Knockdown of $\mathrm{GABA}(\mathrm{A})$ receptor signaling in $\mathrm{GnRH}$ neurons has minimal effects upon fertility. Endocrinology 151:4428-4436. CrossRef Medline

Levine JE (2015) Neuroendocrine control of the ovarian cycle of the rat. In: Knobil and Neill's physiology of reproduction, Ed 4 (Plant TM, Zeleznik AJ, eds), pp 1199-1257. San Diego: Academic Press.

Liu X, Herbison AE (2011) Estrous cycle- and sex-dependent changes in pre- and postsynaptic GABAB control of GnRH neuron excitability. Endocrinology 152:4856-4864. CrossRef Medline
Liu X, Porteous R, d'Anglemont de Tassigny X, Colledge WH, Millar R, Petersen SL, Herbison AE (2011) Frequency-dependent recruitment of fast amino acid and slow neuropeptide neurotransmitter release controls gonadotropin-releasing hormone neuron excitability. J Neurosci 31:2421-2430. CrossRef Medline

Minabe S, Uenoyama Y, Tsukamura H, Maeda K (2011) Analysis of pulsatile and surge-like luteinizing hormone secretion with frequent blood sampling in female mice. J Reprod Dev 57:660-664. Medline

Mitsushima D, Tin Tin Win S, Kimura F (2003) Sexual dimorphism in the GABAergic control of gonadotropin release in intact rats. Neurosci Res 46:399-405.

Moenter SM (2010) Identified GnRH neuron electrophysiology: a decade of study. Brain Res 1364:10-24. CrossRef Medline

Moenter SM, Chu Z, Christian CA (2009) Neurobiological mechanisms underlying oestradiol negative and positive feedback regulation of gonadotrophin-releasing hormone neurones. J Neuroendocrinol 21:327-333. CrossRef Medline

Pape JR, Skynner MJ, Sim JA, Herbison AE (2001) Profiling gammaaminobutyric acid (GABA(A)) receptor subunit mRNA expression in postnatal gonadotropin-releasing hormone $(\mathrm{GnRH})$ neurons of the male mouse with single cell RT-PCR. Neuroendocrinology 74: 300-308. Medline

Penatti CA, Davis MC, Porter DM, Henderson LP (2010) Altered GABAA receptor-mediated synaptic transmission disrupts the firing of gonadotropin-releasing hormone neurons in male mice under conditions that mimic steroid abuse. J Neurosci 30:64976506. CrossRef Medline

Romanò N, Lee K, Abrahám IM, Jasoni CL, Herbison AE (2008) Nonclassical estrogen modulation of presynaptic GABA terminals modulates calcium dynamics in gonadotropin-releasing hormone neurons. Endocrinology 149:5335-5344. CrossRef Medline

Scott CJ, Clarke IJ (1993) Evidence that changes in the function of the subtypes of the receptors for gamma-aminobutyric acid may be involved in the seasonal changes in the negative-feedback effects of oestrogen on gonadotropin-releasing hormone secretion and plasma luteinizing hormone levels in the ewe. Endocrinology 133:2904-2912. CrossRef Medline

Shimshek DR, Bus T, Grinevich V, Single FN, Mack V, Sprengel R, Spergel DJ, Seeburg PH (2006) Impaired reproductive behavior by lack of GluR-B containing AMPA receptors but not of NMDA receptors in hypothalamic and septal neurons. Mol Endocrinol 20:219-231. CrossRef

Silveira M, Burger LL, DeFazio RA, Wagenmaker ER, Moenter SM (2017) $\mathrm{GnRH}$ neuron activity and pituitary response in estradiolinduced vs proestrous luteinizing hormone surges in female mice. Endocrinology 158:356-366. CrossRef Medline

Sim JA, Skynner MJ, Pape J-R, Herbison AE (2000) Late postnatal reorganization of GABA(A) receptor signaling in native $\mathrm{GnRH}$ neurons. Eur J Neurosci 12:3497-3504. Medline

Spergel DJ, Kruth U, Hanley DF, Sprengel R, Seeburg PH (1999) GABA-and glutamate-activated channels in green fluorescent protein-tagged gonadotropin-releasing hormone neurone in transgenic mice. J Neurosci 19:2037-2050.

Suter KJ, Song WJ, Sampson TL, Wuarin JP, Saunders JT, Dudek FE, Moenter SM (2000) Genetic targeting of green fluorescent protein to gonadotropin-releasing hormone neurons: characterization of whole-cell electrophysiological properties and morphology. Endocrinology 141:412-419. CrossRef Medline

Tada H, Kuroki Y, Funabashi T, Kamiya Y, Goto T, Suyama K, Sano A, Mitsushima D, Etgen AM, Takahashi T (2013) Phasic synaptic incorporation of GluR2-lacking AMPA receptors at gonadotropinreleasing hormone neurons is involved in the generation of the luteinizing hormone surge in female rats. Neuroscience 248:664669. CrossRef Medline

Terasawa E, Fernandez DL (2001) Neurobiological mechanisms of the onset of puberty in primates. Endocr Rev 22:111-151. CrossRef Medline 
Todman MG, Han SK, Herbison AE (2005) Profiling neurotransmitter receptor expression in mouse gonadotropin-releasing hormone neurons using green fluorescent protein-promoter transgenics and microarrays. Neuroscience 132:703-712. CrossRef Medline

Vastagh C, Rodolosse A, Solymosi N, Liposits Z (2016) Altered expression of genes encoding neurotransmitter receptors in $\mathrm{GnRH}$ neurons of proestrous mice. Front Cell Neurosci 10:230. CrossRef Medline
Yin C, Ishii H, Tanaka N, Sakuma Y, Kato M (2008) Activation of A-type gamma-amino butyric acid receptors excites gonadotrophin-releasing hormone neurones isolated from adult rats. J Neuroendocrinol 20:566-575. CrossRef Medline

Zhang C, Bosch MA, Rønnekleiv OK, Kelly MJ (2009) Gammaaminobutyric acid $B$ receptor mediated inhibition of gonadotropin-releasing hormone neurons is suppressed by kisspeptin-G protein-coupled receptor 54 signaling. Endocrinology 150:23882394. CrossRef Medline 